\title{
SUNK COSTS HYSTERESIS IN SPANISH MANUFACTURING EXPORTS*
}

\author{
Juan A. Máñez, María E. Rochina and Juan A. Sanchis Llopis**
}

WP-EC 2004-17

Corresponding author: Juan A. Máñez-Castillejo, Universidad de Valencia, Facultad de Economía, Departamento de Economía Aplicada II, Avda. de los Naranjos s/n, 46022 Valencia (Spain); telephone: 0034 963828356, fax: 0034 963828354, e-mail address: jamc@uv.es.

Editor: Instituto Valenciano de Investigaciones Económicas, S.A.

Primera Edición Septiembre 2004.

Depósito Legal: V-3978-2004

IVIE working papers offer in advance the results of economic research under way in order to encourage a discussion process before sending them to scientific journals for their final publication.

\footnotetext{
* Financial support from the Instituto Valenciano de Investigaciones Económicas and the Ministerio de Ciencia y Tecnología (SEC2002-03812) is gratefully acknowledged.

** Juan A. Máñez-Castillejo; María E. Rochina y J.A. Sanchis: Universidad de Valencia, Facultad de Economía, Departamento de Economía Aplicada II, Avda. de los Naranjos s/n, 46022 Valencia (Spain).
} 


\title{
SUNK COSTS HYSTERESIS IN SPANISH MANUFACTURING EXPORTS
}

\author{
Juan A. Máñez, María E. Rochina and Juan A. Sanchis Llopis
}

\begin{abstract}
This paper tests the sunk costs explanation for hysteresis in exports using a sample of Spanish manufacturing firms for the period 1990-2000. The data are drawn from the Spanish Encuesta sobre Estrategias Empresariales. To obtain consistent estimates for sunk costs, we control for all other sources of persistence and use a dynamic random effects multivariate probit model that is estimated through pseudo simulated maximumlikelihood techniques. Our results support the sunk costs explanation for hysteresis. Furthermore, regional spillovers and some firm characteristics such as size, productivity or vertical and horizontal product differentiation are found to have a significant influence on the probability of exporting.
\end{abstract}

Key words: hysteresis in trade, sunk costs, dynamic discrete choice models JEL classification: F12, L1, C23, C25

\section{Resumen}

El objetivo de este artículo es analizar el papel de los costes irrecuperables como factor explicativo de la histéresis de las exportaciones. Para ello se hace uso de una muestra de empresas industriales españolas para el período 1999-2000, que proviene de la Encuesta sobre Estrategias Empresariales. Con el objetivo de obtener estimaciones consistentes para los costes irrecuperables, controlamos por todas las posibles fuentes alternativas de persistencia y estimamos nuestro modelo usando técnicas de pseudo máxima verosimilitud simulada. Nuestros resultados confirman a los costes irrecuperables como causante de la histéresis de las exportaciones. Adicionalmente, encontramos que las externalidades regionales y algunas características empresariales tales como tamaño, productividad o diferenciación horizontal y vertical tienen un impacto significativo sobre la probabilidad de exportar.

Palabras Clave: Histéresis de las exportaciones, costes irrecuperables, modelos dinámicos de elección discrecional 


\section{Introduction.}

In the analysis of the decision to export it seems sensible to think that firms face costs associated with entering foreign markets that may be sunk in nature. For instance, non-exporting firms have to research foreign demand and competition, establish marketing and distribution channels, adjust their product characteristics and packaging to meet foreign tastes and/or fulfil quality and security legislation of other countries.

Acknowledging the existence of sunk costs implies that current exports depend on past export trajectories and, more interestingly, that transitory changes in trade policy or conditions may lead to permanent changes in market structure, that is, sunk entry or exit costs produce hysteresis in export flows. ${ }^{1}$ Furthermore, when there is uncertainty about market conditions, the existence of sunk costs affects the entry and exit patterns as trade flows are less responsive to changes in market conditions, such as exchange rates or incentives (subsidies) for exports.

It is important to note that although persistence in exporting status might be caused by sunk costs, it might also be due to either underlying (observed and unobserved) firm heterogeneity or serial correlation in transitory shocks to exporting profits. Therefore, in order to identify the role of sunk costs one would need an econometric framework that allows controlling for all competing sources of persistence in export behaviour.

The first attempt to tackle the sunk-cost hysteresis hypothesis in the empirical literature on exporting is Roberts and Tybout (1997), who directly analyse entry and exit patterns using plant-level panel data for Colombian manufacturing. More recent empirical evidence on sunk costs hysteresis are Bernard and Wagner (1998), Bernard and Jensen (2004) and Campa (2004), for German plants, U.S. plants and Spanish firms, respectively.

The objective of this paper is to assess the importance of sunk costs hysteresis examining the decision of firm export participation, using panel data for Spanish manufacturing firms, drawn from the Encuesta sobre Estrategias Empresariales (hereafter, ESEE), for the 1990s. To account for different causes of persistence we

\footnotetext{
${ }^{1}$ The theoretical literature on sunk costs and exporting was developed by Dixit (1989a,b), Baldwin (1988), Baldwin (1989), Baldwin and Krugman (1989) and Krugman (1989).
} 
implement a dynamic random effects multivariate probit model, which is estimated by simulated maximum likelihood techniques.

The main contributions of our work to the existing literature are the following. First, we use an extensive set of firm specific and market characteristics to account for observed firm/market heterogeneity, paying special attention to vertical and horizontal product differentiation, and spillovers. Secondly, whereas previous works impose a structure on the serial correlation of transitory shocks (Roberts and Tybout, 1997, Bernard and Wagner, 1998, and Bernard and Jensen, 2004), we allow for a free serial correlation. Misspecification problems may arise from a given structure and may lead to inconsistent estimates for sunk costs. Finally, different to other empirical studies using plant data (Roberts and Tybout, 1997, Bernard and Wagner, 1998, and Bernard and Jensen, 2004), we have firm data, which are the observation units appropriate for modelling the export decision.

As in Campa (2004) we also analyse the decision to export by Spanish firms. However, our work differs from Campa's (2004) in the following respects. First, when modelling the export decision Campa (2004) considers a limited set of firm and market characteristics. By widening this set, identification of sunk costs is improved. ${ }^{2}$ Secondly, Campa's (2004) estimation method does not allow for serial correlation in transitory shocks. As such, this unmodeled persistence in the error structure may have been picked up by the variables capturing past exporting trajectories and thus incorrectly interpreted as sunk costs. However, our estimation method allows for this serial correlation. Thirdly, whereas our work considers data from 1990 to 2000, the sample period in Campa (2004) only covers until 1997. Finally, Campa's (2004) restriction about sunk costs being independent of the firm's history prior to the previous year prevents him from examining the speed of depreciation of the exporting experience. Our analysis, by allowing sunk costs to be a function of a longer exporting history, improves the understanding of the dynamics of participation in foreign markets.

Our results suggest that, even after controlling for unobserved firm heterogeneity and serial correlation in transitory shocks, sunk costs and observed firm heterogeneity are important determinants of the export decision. Hence, we find evidence to support the sunk costs explanation of the hysteresis hypothesis. Our results also indicate that firms leaving the export market suffer a rapid depreciation of their exporting

\footnotetext{
2 As specifically stated by Campa (2004), his paper does not focus on the characteristics of the firms that enter or exit the export market. His main focus is the responsiveness of Spanish export supply to changes in the exchange rate.
} 
experience. Furthermore, we find that firms which are larger, more productive and have higher R\&D and advertising intensities enjoy a higher probability of exporting. Regional spillovers also have a positive impact on this probability.

These findings contribute to better understand the determinants of the firm's decision to export and suggest possible export promotion policies. On the one hand, policies oriented to improve information and access to foreign markets by providing exporting infrastructures could reduce the sunk costs of entry. On the other hand, policies directed at increasing productivity or stimulating product differentiation behaviours would have a positive impact on exporting.

The rest of the paper is organised as follows. In section 2 we present the data and analyse export patterns for Spanish manufacturing. Section 3 is devoted to modelling, estimation issues and variables. The estimation results are summarised in section 4 . Finally, section 5 concludes.

\section{Data and export patterns.}

\subsection{The data.}

We use data drawn from the ESEE, a representative annual survey of Spanish manufacturing firms carried out since 1990, which includes exhaustive information at the firm level.

The sampling procedure of the ESEE is the following. In the base year, 1990, firms were chosen using a selective sampling scheme with different participation rates depending on firm size. All firms with more than 200 employees (large firms) were requested to participate and the participation rate reached approximately $70 \%$ of the number of firms in the population. Firms that employed between 10 to 200 (small firms) were randomly sampled by industry and size strata, holding around 5\% of the population. ${ }^{3}$ Hence, the coverage of the dataset is different depending on the size group of firms. The different sampling properties of these two size groups advice to carry out a separate analysis of the representativeness of the sample and export patterns by size

\footnotetext{
${ }^{3}$ Firms with less than 10 employees in 1990 were not included in the survey.
} 
group. The influence of size in the export decision will be also taken into account in the econometric analysis.

We select a panel of continuously operating firms over the period 1990-2000. The choice of a continuous panel is motivated by two reasons. First, to analyse firm's export trajectories for the maximum length of time, we sample out those firms that fail to supply export information in any year. Second, to estimate a dynamic specification with lagged endogenous variables, we need to build up a panel as long as possible. Furthermore, we drop any firm that failed during the sampling period. ${ }^{4}$ After applying these criteria, we end up with a balanced panel of 755 firms.

Table 1 shows that, in our sample, small firms are slightly over-represented when compared to the complete sample: in 1990, their proportion in total firms and their shares in total employment, sales and exports are larger.

Table 1: Sample representativeness: large versus small firms, 1990.

\begin{tabular}{lcccc}
\hline & \multicolumn{2}{c}{1990 complete sample } & \multicolumn{2}{c}{ Continuing Sample 1990 } \\
& Small firms & Large firms & Small firms & Large firms \\
\hline Number of firms & 1475 & 709 & 538 & 217 \\
\% of total sample & $67.54 \%$ & $32.46 \%$ & $71.26 \%$ & $28.74 \%$ \\
\% of total employment & $9.30 \%$ & $90.70 \%$ & $13.26 \%$ & $86.74 \%$ \\
\% of total sales & $6.71 \%$ & $93.29 \%$ & $11.41 \%$ & $88.59 \%$ \\
\% of total exports & $4.83 \%$ & $95.18 \%$ & $8.32 \%$ & $91.68 \%$ \\
\hline
\end{tabular}

Table 2 shows that, regardless of size group, firms in our sample are smaller (as measured by the number of employees) and export a higher proportion of their sales than firms in the complete sample. However, other relevant characteristics such as the sample probability of being an exporter/non-exporter or the share of exporting firms on total sales and employment are similar in both samples. We therefore consider that our sample is suitable to estimate the probability of exporting.

\footnotetext{
${ }^{4}$ Including these firms would involve to model the probability of failing and would substantially complicate the analysis. However, this assumption is not innocuous, as shown in Esteve, Sanchis and Sanchis (2003), where using a sample drawn from the ESEE, they find that exporting firms are less likely to fail.
} 
Table 2: Sample representativeness: exporters versus non-exporters, 1990.

\begin{tabular}{lrrrr}
\hline & \multicolumn{2}{c}{1990 complete sample } & \multicolumn{2}{c}{ Continuing Sample 1990 } \\
& Non-Exporters & Exporters & Non-exporters & Exporters \\
\hline 1. Small firms & 1017 & 458 & 356 & 182 \\
Number of firms & $68.95 \%$ & $31.05 \%$ & $66.17 \%$ & $33.83 \%$ \\
\% of total sample & 30 & 58 & 28 & 56 \\
Average size (employees) & - & $22.70 \%$ & - & $22.95 \%$ \\
Exports/Sales (average) & $53.15 \%$ & $46.85 \%$ & $49.49 \%$ & $50.51 \%$ \\
$\%$ of total employment & $47.25 \%$ & $52.75 \%$ & $43.82 \%$ & $56.17 \%$ \\
\% of total sales & & & & \\
\hline 2. Large firms & 119 & 590 & 34 & 183 \\
Number of firms & $16.78 \%$ & $83.22 \%$ & $15.67 \%$ & $84.33 \%$ \\
\% of total sample & 452 & 841 & 349 & 658 \\
Average size (employees) & - & $21.20 \%$ & - & $27.23 \%$ \\
Exports/Sales (average) & $9.78 \%$ & $90.22 \%$ & $8.98 \%$ & $91.02 \%$ \\
$\%$ of total employment & $8.49 \%$ & $91.51 \%$ & $7.17 \%$ & $92.83 \%$ \\
\% of total sales & & & \\
\hline
\end{tabular}

Table 3 reports characteristics of our sample on export activity by size group for the period 1990-2000. The proportion of exporting firms steadily increased for both groups along the period, though such proportion always remained higher for large firms. In particular, the proportion of small firms exporting rose from $33.83 \%$ to $52.50 \%$ and of large firms from $84.33 \%$ to $94.36 \%$. At the same time, the participation of exports on sales grew much faster for large firms than for small ones. This is explained by two factors: first, the annual growth rate of exports is larger for large firms than for small ones (11.95\% and $10.34 \%$, respectively) and second, the annual growth rate of sales is larger for small firms than for large ones (5.63\% and 5.10\%, respectively). Hence, whilst the fraction of exports on sales for large firms is under 1.5 times that for small firms $(21.37 \%$ and $15.08 \%$, respectively) in 1990 , it is almost double $(42.39 \%$ and $24.16 \%$, respectively) by 2000 . 
Table 3: Export characteristics.

\begin{tabular}{|c|c|c|c|c|c|c|c|c|c|c|c|}
\hline & 1990 & 1991 & 1992 & 1993 & 1994 & 1995 & 1996 & 1997 & 1998 & 1999 & 2000 \\
\hline \multicolumn{12}{|l|}{ 1. Small firms } \\
\hline Number of Exporters & 182 & 186 & 226 & 236 & 244 & 267 & 281 & 279 & 283 & 281 & 294 \\
\hline Number of Non-exporters & 356 & 356 & 336 & 342 & 327 & 303 & 292 & 284 & 279 & 284 & 266 \\
\hline$\%$ of Exporters & $33.83 \%$ & $34.32 \%$ & $40.21 \%$ & $40.83 \%$ & $42.73 \%$ & $46.84 \%$ & $49.04 \%$ & $49.56 \%$ & $50.36 \%$ & $49.73 \%$ & $52.50 \%$ \\
\hline Total Sales & 264.347 & 278.074 & 303.439 & 355.360 & 369.394 & 386.450 & 439.094 & 440.377 & 464.394 & 497.638 & 464.074 \\
\hline Total Exports & 39.855 & 28.464 & 46.205 & 71.765 & 77.665 & 76.500 & 99.379 & 105.507 & 116.474 & 121.692 & 112.117 \\
\hline Export/Sales (\%) & $15.08 \%$ & $10.24 \%$ & $15.23 \%$ & $20.20 \%$ & $21.02 \%$ & $19.80 \%$ & $22.63 \%$ & $23.96 \%$ & $25.08 \%$ & $24.45 \%$ & $24.16 \%$ \\
\hline \multicolumn{12}{|l|}{ 2. Large firms } \\
\hline Number of Exporters & 183 & 186 & 176 & 164 & 165 & 167 & 162 & 181 & 182 & 182 & 184 \\
\hline Number of Non-exporters & 34 & 27 & 17 & 13 & 19 & 18 & 20 & 11 & 11 & 8 & 11 \\
\hline$\%$ of Exporters & $84.33 \%$ & $87.32 \%$ & $91.19 \%$ & $92.66 \%$ & $89.67 \%$ & $90.27 \%$ & $89.01 \%$ & $94.27 \%$ & $94.39 \%$ & $95.79 \%$ & $94.36 \%$ \\
\hline Total Sales & 2051.610 & 2105.150 & 2074.027 & 1926.421 & 2275.951 & 2512.257 & 2495.921 & 2738.441 & 2935.871 & 3131.059 & 3415.515 \\
\hline Total Exports & 438.374 & 348.354 & 654.719 & 628.722 & 811.500 & 1003.607 & 1032.801 & 1174.564 & 1239.791 & 1308.315 & 1447.843 \\
\hline Export/Sales (\%) & $21.37 \%$ & $16.55 \%$ & $31.57 \%$ & $32.64 \%$ & $35.66 \%$ & $39.95 \%$ & $41.38 \%$ & $42.89 \%$ & $42.23 \%$ & $41.79 \%$ & $42.39 \%$ \\
\hline
\end{tabular}

Total exports and total sales are in thousand of millions of 1990 pesetas. The ratio has been calculated including in sales both sales of exporters and non-exporters.

Table 4: Firms transition rates in the export market 1990-2000.

\begin{tabular}{|c|c|c|c|c|c|c|c|c|c|c|c|c|}
\hline Year $t$ status & Year $t+1$ status & $1990-91$ & $1991-92$ & 1992-93 & 1993-94 & $1994-95$ & $1995-96$ & 1996-97 & $1997-98$ & 1998-99 & 1999-2000 & $\begin{array}{l}\text { Average } \\
1990-2000\end{array}$ \\
\hline \multicolumn{13}{|l|}{ 1. Small firms } \\
\hline \multirow[t]{2}{*}{ No exports } & No Exports & 0.938 & 0.904 & 0.930 & 0.909 & 0.892 & 0.925 & 0.908 & 0.923 & 0.926 & 0.902 & 0.916 \\
\hline & Exports & 0.062 & 0.096 & 0.070 & 0.091 & 0.108 & 0.075 & 0.092 & 0.076 & 0.074 & 0.098 & 0.084 \\
\hline \multirow[t]{2}{*}{ Exports } & No Exports & 0.104 & 0.054 & 0.110 & 0.076 & 0.049 & 0.049 & 0.07 & 0.068 & 0.094 & 0.03 & 0.070 \\
\hline & Exports & 0.896 & 0.946 & 0.890 & 0.924 & 0.951 & 0.951 & 0.93 & 0.932 & 0.906 & 0.97 & 0.930 \\
\hline \multicolumn{13}{|l|}{ 2. Large firms } \\
\hline \multirow[t]{2}{*}{ No exports } & No Exports & 0.735 & 0.767 & 0.875 & 0.808 & 0.806 & 0.897 & 0.633 & 0.857 & 0.842 & 0.937 & 0.816 \\
\hline & Exports & 0.265 & 0.233 & 0.125 & 0.192 & 0.194 & 0.103 & 0.367 & 0.143 & 0.157 & 0.063 & 0.184 \\
\hline \multirow[t]{2}{*}{ Exports } & No Exports & 0.027 & 0.005 & 0.026 & 0.052 & 0.022 & 0.021 & 0.011 & 0.005 & 0 & 0.025 & 0.019 \\
\hline & Exports & 0.973 & 0.995 & 0.974 & 0.948 & 0.978 & 0.979 & 0.989 & 0.995 & 1 & 0.975 & 0.981 \\
\hline
\end{tabular}

The value of each one is the proportion of firms in each of the year $t$ status (exports-no exports) that chooses each of the two possible statuses in year $t+1$. 


\subsection{Entry and exit patterns in the export market.}

To evaluate the importance of the flows in and out of the export market, we analyze the sample transition rates (Table 4). ${ }^{5}$ Each one of the entries in this table gives the proportion of firms in each of the year- $t$ status (export versus non export) that choose each of the two possible statuses in year $t+1$.

The second and third rows of each panel of Table 4, which report the entry and exit rates in/from the export market (i.e., transitions from no exports to exports and from exports to no exports), show that exporting one year does not necessarily mean permanence in this activity. For the group of small firms, the average entry and exit rates are quite similar ( $8.4 \%$ and $7 \%$, respectively) and some years the exit rate exceeds the entry rate, suggesting a high rate of turnover. For large firms, the average entry rate is above $18 \%$ and the exit rate under $2 \%$, pointing out a clear trend of incorporation to the export market and of persistence in that status. Hence, it is very likely that once a large firm starts exporting remains doing so. As a result of these entry and exit rates, there is a net gain of 113 exporters ( 99 out of the 356 non-exporters classified as small in 1990 and 14 out of the 34 non-exporters classified as large, see Table 3). In population terms, this means a net gain of 2000 firms (1980 small and 20 large), suggesting that export became a general activity during the analyzed period. ${ }^{6}$

Together with the substantial entry and exit, there is an important degree of persistence in the exporting status: $63.01 \%$ of small firms and $77.41 \%$ of large firms never change their exporting status. ${ }^{7}$ Columns 1 and 2 of Table 5 present the proportion of exporters and non-exporters in 1990 that had the same status in one of the subsequent 10 years. $^{\mathbf{8}}$ The percentage of small firms that exported in 1990 and were also exporting

\footnotetext{
${ }^{5}$ For the purpose of calculating transition rates, firms have been splitted into size groups according to their employment in 1990. The alternative of using current employment could lead to transition rates higher than $100 \%$, since a number of firms move from the small to the large group and viceversa over time.

${ }^{6}$ These figures have been calculated taking into account the sampling scheme of the ESEE.

7 These figures have been calculated accounting for the firms that always or never export.

${ }^{8}$ We follow Bernard and Jensen (2004) to build up this table. In these columns we do not distinguish between firms that export (not export) continuously and firms that change status. For example, in the percentage of 1996 we include both firms that exported every year from 1990 to 1996 and firms that exported in 1990 and 1996, but not in one or more of the years in between.
} 
in 1995 is slightly above $90 \%$ (five years later this percentage is exactly the same). For large firms persistence is even more intense as 94\% of the firms exporting in 1990 also exported in 1995 and five years later this percentage is even larger, 95.6\%. Persistence in the non-exporting status, though important, is not as intense as in the exporting status. Almost $77 \%$ of small firms that did not export in 1990 did not export five years later, and $67.1 \%$ did not export in 2000. Among large firms, persistence in the non-exporting status is even lower as the aforementioned percentages get reduced to almost $53 \%$ and $35.3 \%$, respectively. This lower rate of persistence for large firms in the non-exporting status confirms the trend of incorporation to the export market detected above.

Table 5: Persistence of exporting (and Non-Exporting).

Proportion of 1990 firms with the same export status.

\begin{tabular}{ccccc}
\hline & $\begin{array}{c}(1) \\
\text { Exporters } \\
\text { Actual }\end{array}$ & $\begin{array}{c}(2) \\
\text { Non-exporters } \\
\text { Actual }\end{array}$ & $\begin{array}{c}(3) \\
\text { Exporters } \\
\text { Expected }\end{array}$ & $\begin{array}{c}(4) \\
\text { Non-exporters } \\
\text { Expected }\end{array}$ \\
\hline 1. Small firms & & & & \\
1991 & $89.56 \%$ & $93.82 \%$ & $89.56 \%$ & $93.82 \%$ \\
1992 & $91.75 \%$ & $88.20 \%$ & $84.72 \%$ & $84.78 \%$ \\
1993 & $89.01 \%$ & $86.80 \%$ & $75.40 \%$ & $78.86 \%$ \\
1994 & $87.91 \%$ & $82.30 \%$ & $69.62 \%$ & $71.66 \%$ \\
1995 & $90.11 \%$ & $76.96 \%$ & $66.19 \%$ & $63.93 \%$ \\
1996 & $89.56 \%$ & $73.87 \%$ & $62.96 \%$ & $59.11 \%$ \\
1997 & $90.66 \%$ & $72.19 \%$ & $58.53 \%$ & $53.66 \%$ \\
1998 & $91.21 \%$ & $71.63 \%$ & $54.54 \%$ & $49.55 \%$ \\
1999 & $87.91 \%$ & $71.34 \%$ & $49.44 \%$ & $45.89 \%$ \\
2000 & $90.11 \%$ & $67.13 \%$ & $47.93 \%$ & $41.40 \%$ \\
\hline 1991 & & & & $73.53 \%$ \\
1992 & $97.26 \%$ & $73.52 \%$ & $97.27 \%$ & $56.37 \%$ \\
1993 & $97.81 \%$ & $58.82 \%$ & $96.75 \%$ & $49.33 \%$ \\
1994 & $95.62 \%$ & $52.94 \%$ & $94.24 \%$ & $39.84 \%$ \\
1995 & $94.53 \%$ & $61.76 \%$ & $89.31 \%$ & $32.13 \%$ \\
1996 & $93.99 \%$ & $52.94 \%$ & $87.39 \%$ & $28.81 \%$ \\
1997 & $93.44 \%$ & $52.94 \%$ & $85.53 \%$ & $18.25 \%$ \\
1998 & $96.17 \%$ & $41.17 \%$ & $84.61 \%$ & $15.64 \%$ \\
1999 & $96.72 \%$ & $38.23 \%$ & $84.18 \%$ & $13.17 \%$ \\
2000 & $96.72 \%$ & $29.41 \%$ & $84.18 \%$ & $12.35 \%$ \\
\hline 2. Large firms & $95.62 \%$ & $35.29 \%$ & $82.09 \%$ & 0 \\
\hline
\end{tabular}

Note: Figures in columns (1) and (2) represent the percentage of exporting (non-exporting) firms in 1990 that were also exporting (non-exporting) in the listed year. Figures in columns (3) and (4) show the expected percentages if entering and exiting firms were chosen randomly with annual transition rates given by the data. For instance, in 1990, the number of exporters in the small firms group was 182 (see Table 3) and from Table 4 we know that the exit rate for the small firms group for the period 1990-1991 is $10.44 \%$. Therefore, the expected number of exporters in 1991 is obtained as $182 *(1-0.1044)=163$, and 163 is approximately $89.56 \%$ of 182 .

Columns 3 and 4 of Table 5 report the predicted rates of persistence in each of the two statuses. These are calculated using the annual transition rates given by the data and presented in Table 4. Regardless of size group, and over the whole sampling period, predicted persistence is lower than (sample) actual persistence. Hence, we can extract two conclusions: first, the probability of exporting is higher for firms that have exported before, i.e. there is a high rate of re-entry by former exporters; second, firms in the 
export market with a non-exporting past have a higher probability of leaving the export market.

So far we have detected that export participation shows a high level of persistence across firms in the sample by size group. Now, we analyze if there exists heterogeneity of entry and exit rates across industries. Figure 1 shows average annual firm entry and exit rates for the 20 manufacturing sectors of the NACE-93 classification and the overall sample of firms. ${ }^{9}$ While some industries exhibit turnover patterns that are similar to the overall sample, other industries (such as leather and shoes, printing and printing stuff, rubber and plastic products, metallurgy, office machines, motors and cars, other transport materials, furniture or other manufacturing goods) show entry or exit rates that substantially differ from those of the overall sample. ${ }^{\mathbf{1 0}}$ This suggests that firm/market characteristics are likely to be important determinants of the export decision.

\section{Figure 1: Industry average rates of entry and exit in the export market.}

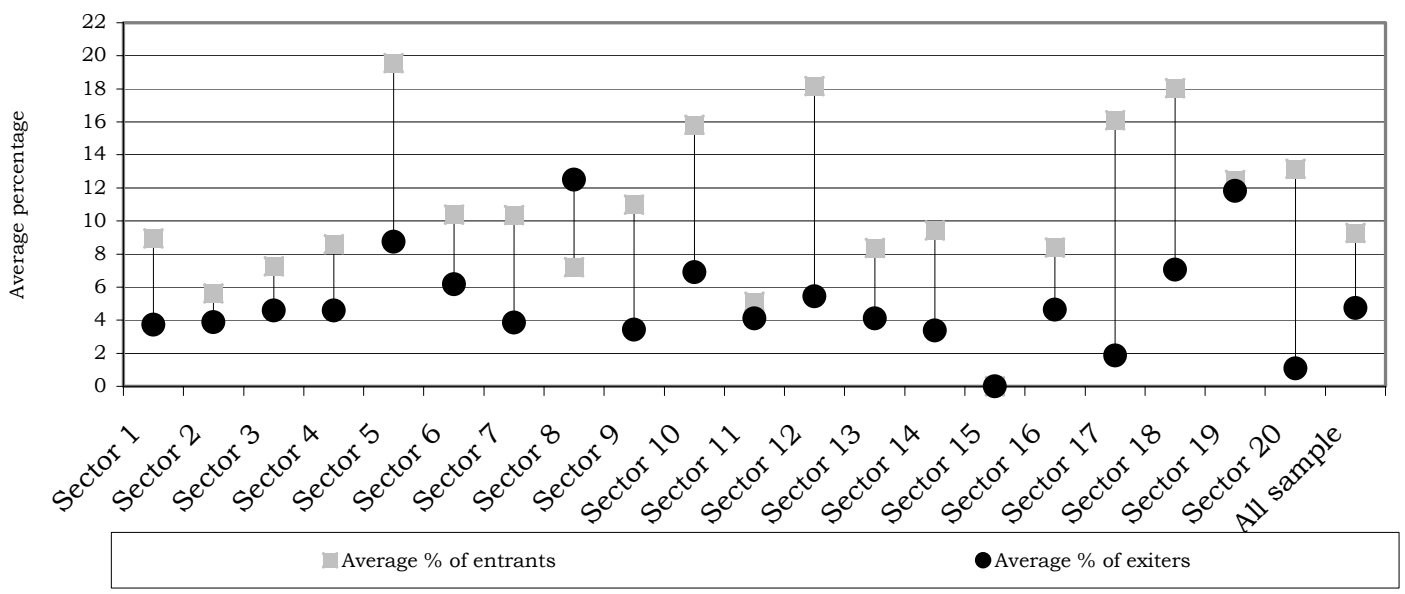

* See Table 6 for the sector classification.

The aim of next section is to present an econometric model to investigate the role of sunk costs and firm and industry characteristics in explaining observed exporting status persistence.

\footnotetext{
${ }^{9}$ The industry classification can be found in at the bottom of Table 6 .

${ }^{10}$ An extreme case is the office machines sector, with no change of exporting status over the period.
} 


\section{Modelling and estimation.}

\subsection{Modelling the export decision.}

We follow Roberts and Tybout (1997) in modelling the decision to export by a rational, profit-maximizing firm. The firm considers expected profits (net of entry and exit sunk costs) derived from that decision. In each period $t$ the variation in gross profits adjusted for sunk costs is given by

$$
\hat{\pi}_{i t}=y_{i t}\left[\pi_{i t}\left(p_{t}, s_{i t}\right)-F_{i t}^{0}\left(1-y_{i, t-1}\right)-\sum_{j=2}^{J_{i}}\left(F_{i t}^{j}-F_{i t}^{0}\right) \tilde{y}_{i, t-j}\right]-G_{i t} y_{i, t-1}\left(1-y_{i t}\right)
$$

where $y_{i t}$ takes the value of 1 if the firm exports in period $t$ and 0 otherwise. $\pi_{i t}$ is the current increase to gross profits associated with the decision to export; firm-specific characteristics, market characteristics and spillovers are included in $s_{i t}$; and other factors, such as aggregate exchange rate movements, trade policy conditions, etc., are included in $p_{t} . J_{i}$ is the age of the firm and $\tilde{y}_{i, t-j}=\left(y_{i, t-j} \prod_{k=1}^{j-1}\left(1-y_{i, t-k}\right)\right)$ summarizes the firm recent export experience and takes the value of 1 if the last period that firm $i$ exported was period $t-j$ and 0 otherwise. To account for sunk costs the following assumptions are made. First, a firm that has never exported faces an entry cost of $F_{i t}^{0}$ and would earn the first year exporting $\pi_{i t}\left(p_{i t}, s_{i t}\right)-F_{i t}^{0}$. Second, a firm that exported in the previous year, i.e. if $y_{i, t-l}=1$, does not have to pay the entry cost in $t$ and would earn $\pi_{i t}\left(p_{t}, s_{i t}\right)$, but if this firm decides to exit it would incur in an exit cost represented by $-G_{i t}$. Finally, firms that abandon the export activity in previous periods $(t-j$ with $j \geq 2$ ) and decide to re-start exporting again are also considered. In this case, we assume that the firm faces a re-entry cost of $F_{i t}^{j}$, which would leave the firm earnings $\pi_{i t}\left(p_{i}, s_{i t}\right)-F_{i t}^{j}$. The $j$ subscript indicates that re-entry costs depend on the length a firm has been away from exporting. This could reflect the depreciation of knowledge and experience accumulated during the exporting period or the increasing cost of updating products, market channels, etc., to the "changing" foreign markets. 
We assume that in period $t$ managers plan the firm export participation sequence that maximises the expected current and discounted future profits net of sunk costs. ${ }^{11}$ This maximised payoff is,

$$
V_{i t}=\max _{\left|y_{i s}\right|_{s=t}^{\infty}} E_{t}\left(\sum_{s=t}^{\infty} \delta^{s-t} \hat{\pi}_{i s}\right)
$$

where $E_{t}$ is an expectations operator conditioned on the set of firm information at time $t$ and $\delta$ is a time discount rate. Firm $i$ chooses the current $y_{i t}$ value that satisfies the Bellman's equation:

$$
V_{i t}=\max _{y_{i t}} \hat{\pi}_{i t}+\delta E_{t}\left[\left.V_{i, t+1}|| y_{i t-j}\right|_{j=0} ^{J_{i}}\right]
$$

A firm that decides to export in $t$ gets the expected present value of payoffs

$$
\pi_{i t}+\delta E_{t}\left(\left.V_{i, t+1}\left|y_{i t}=1,\right| y_{i t-j}\right|_{j=1} ^{J_{i}}\right)-F_{i t}^{0}\left(1-y_{i, t-1}\right)-\sum_{j=2}^{J_{i}}\left(F_{i t}^{j}-F_{i t}^{0}\right) \tilde{y}_{i, t-j}
$$

and one that decides not to do it

$$
\delta E_{t}\left(\left.V_{i, t+1}\left|y_{i t}=0,\right| y_{i t-j}\right|_{j=1} ^{J_{i}}\right)-G_{i t} y_{i, t-1}
$$

The ith firm will decide to export during period $t$ whenever (4) minus (5) is positive, i.e.

$$
\pi_{i t}+\delta\left[E_{t}\left(V_{i, t+1} \mid y_{i t}=1\right)-E_{t}\left(V_{i, t+1} \mid y_{i t}=0\right)\right]-F_{i t}^{0}+\left(F_{i t}^{0}+G_{i t}\right) y_{i, t-1}-\sum_{j=2}^{J_{i}}\left(F_{i t}^{j}-F_{i t}^{0}\right) \tilde{y}_{i, t-j} \geq 0
$$

The empirical specification is derived from (6). Defining the latent variable $\pi_{i t}^{*}$ as current gross operating profits plus the discounted expected future return from being an exporting firm in year $t$,

$$
\pi_{i t}^{*}=\pi_{i t}+\delta\left[E_{t}\left(V_{i, t+1} \mid y_{i t}=1\right)-E_{t}\left(V_{i, t+1} \mid y_{i t}=0\right)\right]
$$

\footnotetext{
${ }^{11} \mathrm{We}$ assume that the firm also chooses the profit-maximizing level of exports if it decides to export.
} 
export participation is then given by the following dynamic discrete choice process:

$y_{i t}=\left\{\begin{array}{ccc}1 & \text { if } & \pi_{i t}^{*}-F_{i t}^{0}+\left(F_{i t}^{0}+G_{i t}\right) y_{i, t-1}-\sum_{j=2}^{J_{i}}\left(F_{i t}^{j}-F_{i t}^{0}\right) \tilde{y}_{i, t-j} \geq 0 \\ 0 & \text { otherwise. }\end{array}\right.$

We approximate $\pi_{i t}^{*}-F_{i t}^{0}$ as a reduced-form expression on exogenous firm/market characteristics and spillovers $\left(X_{\mathrm{it}}\right)$, macro conditions $\left(\mu_{t}\right)$, and noise $\left(\varepsilon_{i t}\right){ }^{12}$ Therefore,

$\pi_{i t}^{*}-F_{i t}^{0}=\mu_{t}+\beta X_{i t}+\varepsilon_{i t}$.

We also consider some identifying assumptions in relation to sunk entry, reentry and exit costs. First, we assume that sunk costs do not vary across time. Second, we suppose that sunk entry costs for firms which did not export for at least $J$ years are the same, $F_{i}^{0}=F^{0}$, and that all firms which did not export for $j<J$ years incur in the same re-entry sunk costs, $F_{i}^{j}=F^{j}$. Finally, we consider that all firms currently exporting have the same exit cost $G_{i}=G$.

Using the above assumptions, re-defining $F^{0}-F^{j}=\gamma^{j}$ for $j=2, \ldots, J$, $F^{0}+G=\gamma^{0}$, and substituting (9) into (8), we have the estimation equation:

$y_{i t}= \begin{cases}1 & \text { if } \mu_{t}+\beta X_{i t}+\gamma^{0} y_{i, t-1}+\sum_{j=2}^{J} \gamma^{j} \tilde{y}_{i, t-j}+\varepsilon_{i t} \geq 0 \\ 0 & \text { otherwise. }\end{cases}$

Notice, from last expression, that the export decision in $t$ does not depend on the firm exporting background if sunk costs are zero. This allows checking for the importance of sunk costs by testing whether $\gamma^{0}$ and $\gamma^{j}$, for $j=2, \ldots, J$, are jointly equal to zero. It is also possible to analyse the rate of depreciation of experience and accumulated knowledge in export activities by looking at these coefficients individually.

\footnotetext{
${ }^{12}$ All of them, with the exception of $\varepsilon_{i t}$, are assumed to be observable to the firm in period $t$.
} 


\subsection{Estimation issues.}

Given that we are interested in isolating the effects of sunk costs hysteresis (true state dependence) in the exporting status, it is crucial to control for all other sources of persistence. Most of this task is accomplished by including the vector of observable characteristics $X_{i t}$ in (10). However, it is highly probable that there still remain unobserved factors causing persistence such as product attributes, foreign contacts, managerial ability and technology. Since they are potentially permanent, or highly serially correlated, in practice we assume that $\varepsilon_{i t}$ in (10) has two components, a permanent firm-specific effect $\left(\alpha_{i}\right)$ and a transitory component $\left(u_{i t}\right)$. Hence, we allow for two sources of serial correlation in $\varepsilon_{i t}$, the first arising from the permanent component and the second from serial correlation in transitory shocks to exporting profits. We further assume that the $\operatorname{cov}\left(X_{i t}, \varepsilon_{i t}\right)=0 \forall i, t$, and normalize $\operatorname{Var}\left(\varepsilon_{i t}\right)=1$.

It is also needed to address an "initial conditions" problem. We observe a firm exporting status in years 1 through $T$, and our lag structure reaches back $J$ periods. Values corresponding to the first $J$ years $\left(y_{i 1}, \ldots, y_{i J}\right)$ cannot be treated as exogenous determinants of $y_{i t}$, when $t>J$, because each one depends on $\alpha_{i}$ and previous realizations of $u_{i t}$, both of which are correlated with $\varepsilon_{i t}$. Heckman (1981) suggests dealing with this initial conditions problem by using an approximate representation for $y_{i t}$ when $t \leq J$. Specifically, let us suppose that expected profits in the export market during the $J$ pre-sample years can be represented by the equation

$$
\pi_{i t}^{*}-F_{i t}^{0}=\lambda X_{i t}^{p}+\varepsilon_{i t}^{p}
$$

where $X_{i t}^{p}$ is a distributed lag in pre-sample realizations on exogenous variables. ${ }^{13}$ Then, presample export-participation is described by

$$
y_{i t}= \begin{cases}1 & \text { if } \lambda X_{i t}^{p}+\varepsilon_{i t}^{p} \geq 0 \\ 0 & \text { otherwise }\end{cases}
$$

\footnotetext{
13 In the empirical work all the firm characteristics $\left(X_{i t}\right)$ are included as explanatory variables in $X_{i t}^{p}$. We also include two-year lagged values of the firm's continuous variables.
} 
instead of equation (10). We assume that $\varepsilon_{i t}^{p}$ has the same properties than $\varepsilon_{i t}$. Furthermore, it is assumed that the joint distribution of $\varepsilon_{i 1}^{P}, \ldots, \varepsilon_{i J}^{P}, \varepsilon_{i J+1}, \ldots, \varepsilon_{i T}$ is multivariate standard normal, and its full correlation matrix is characterised by $\{(T \times T)-T\} / 2$ free distinct (and estimable) correlations, with ones on the diagonal and $\rho_{t s}=\rho_{s t}$ as off-diagonal elements. ${ }^{14}$ Roberts and Tybout (1997), Bernard and Wagner (1998) and Bernard and Jensen (2004) impose an AR(1) on the serial correlation of the transitory components of $\varepsilon_{i t}$ and $\varepsilon_{i t}^{p}$. Campa (2004) does not allow for correlation of these components. Nevertheless, we leave it fully unrestricted.

Positive (negative) signs in the set of correlation coefficients between the disturbances of the first $J$ periods and the disturbances in every other period, indicate that firms that were more likely to be exporters in initial conditions years were more (less) likely to remain exporters during sample years compared to the non-exporters. If these correlation coefficients are jointly equal to zero, there is no initial conditions problem and the model reduces its dimension to a $T$ - $J$ multivariate probit model. And if $\rho_{t s}, \forall t \neq s$, are all jointly equal to zero, then exporting equations may be estimated using simple univariate probit models. We estimate the general model with free correlations and test for special cases.

Our general model is a dynamic random effects multivariate probit model, where we solve the computational problem of $\mathrm{T}$-dimensional integrals using simulated maximum likelihood (SML) techniques. We use the Geweke-Hajivassiliou-Keane (GHK) simulator to replace multivariate standard normal probability distribution functions by their simulated counterparts. ${ }^{15}$ Additionally, we use a pseudo maximum likelihood estimator, which adjusts the estimates of the parameter covariance matrix to account for arbitrary correlations between all the panel observations of a given firm (see Huber, 1967, Binder, 1983, and White, 1982). The estimator is then a Pseudo Simulated Maximum Likelihood (PSML) estimator. ${ }^{16}$

\footnotetext{
${ }^{14}$ In our empirical work $J=3$ and $T=10$.

15 See Hajivassiliou and Ruud (1994) and Gourieroux and Monfort (1996).

${ }^{16}$ A Stata program that implements this estimator is available from Cappellari and Jenkins (2003).
} 


\subsection{Explanatory variables.}

To parameterize the firm's exporting decision given by equation 10, we assume that variation in export profitability and start-up costs (other than unobserved components) may arise from four different sources: time-specific effects, industry dummies, observable differences in firm/market characteristics and spillovers.

Time effects are included in order to capture macro-level changes in export conditions that are common across firms, such as the influence of business cycle, creditmarket conditions, aggregate exchange rate movements (affecting relative prices from exporting and domestic sales), trade-policy, overall changes in demand for Spanish exports and other time-varying factors. Industry dummies to control for unobservable characteristics of markets where firms compete, such as market concentration, use of technology or firms' specific behaviour by industry, are also included.

We also consider several hypotheses concerning the role of observable firm characteristics. Perhaps the most obvious are those related to past success. Although the usual claim is that better performing firms become exporters, a substantial fraction of export policies assumes instead that exporters will become good performing firms. To proxy for firm success we include age, size and productivity. Age proxies for efficiency differences. If market forces select out inefficient producers, older firms will tend to be more competitive in world markets, either because of cost advantages that cannot be imitated by rivals or because they have had time to move down along a learning curve. ${ }^{17}$ As pointed out by Bernard and Jensen (1999), even if the annual payoffs from exporting were the same for young and old firms, the young ones would perceive smaller returns from entering the export market because they face a higher risk of failure. Size may proxy for several effects: larger firms have been usually successful in the past, but size may be associated with lower average or marginal costs, providing a separate mechanism for size to increase the likelihood of exporting. Another link between size and export may reflect scale economy-based exporting (Krugman, 1984). Furthermore, size may be picking up other factors such as better access to specific inputs, information, etc., which can affect firm performance. There are also reasons to expect firm productivity to increase the likelihood of exporting.

\footnotetext{
${ }^{17}$ Roberts (1996) reports a decline in the probability of failure as a plant ages for Colombia and Tybout (1996) reports a similar finding for Chile. The same pattern has been found in data from the US (see Dunne et al., 1989 or Baily et al., 1992).
} 
If the fixed costs of selling are higher in the export market than in the domestic market or if output prices are lower, only firms with high productivity will find it profitable to enter the export market. This is usually referred to as the self-selection hypothesis in the models of industry dynamics. ${ }^{18}$

We discuss next the role of quality of the labour-force. If exported goods have higher quality, a higher value to weight ratio or require new product design and other forms of technical assistance, then we would expect the quality of the workforce to be positively related to entrance into foreign markets.

A sizable body of research has focused on the role of ownership in cross-border trade. We control for the ownership structure of the firm (limited liability Corporation versus other, and foreign capital participation). One can think that non-domestically owned firms may enjoy better access to foreign markets due to complementarities with other business within the same group. It has been frequently argued that firms participated by foreign capital are, in general, more efficient and so their presence in foreign markets should be higher. Furthermore, when foreign direct investment is based on competitive advantages of the destination market, it is expected a positive relation between foreign ownership and exporting activity. In this case, the domestic market might be seen as a productive platform.

The decision to export can also be affected by domestic demand factors such as the evolution of domestic demand or the type of customer. If foreign markets became a relevant alternative in periods of low domestic demand, we would expect the probability of exporting to be higher in these periods. If a firm's main customer is the public sector (due to the nature of the product) whenever this firm decides to export it will have to face the possible preference of the foreign public sector for its own national producers. It can also happen that once domestic producers have adapted their production to meet the requirements of their domestic public sector, they may not be very much attracted by foreign markets.

We also consider the effects of vertical and horizontal product differentiation strategies. As vertical differentiation is related to product quality differentiation, we proxy for it by using variables that measure the firm innovation-related activities such as R\&D intensity, complementary technological activities and innovation results. We

\footnotetext{
${ }^{18}$ See for example, Ericson and Pakes (1995), Pakes and Ericson (1998) or Baldwin and Rafiquzzaman (1995). Delgado, Fariñas and Ruano (2002) find evidence supporting the self-selection hypothesis using data drawn from the ESEE.
} 
would expect that the higher the vertical differentiation of the firm, the higher the probability of exporting. To account for horizontal differentiation, which is more identified with different product perceptions from the demand side, we include firm's advertising intensity.

The literature on economic geography and trade (Krugman 1992) hypothesizes that activities of neighbouring firms may reduce entry costs. The presence of other exporters may make it easier, for domestically oriented firms, to break into foreign markets. A form of externality might arise if the presence of other exporters lowers the cost of production, possibly by increasing the availability of specialized capital and labour inputs. We consider three forms of spillovers: region-specific, industry-specific and local to the industry and region. ${ }^{19}$

Finally, in order to assess the importance of sunk costs, we use a lag structure for past participation that reaches back three periods. As noticed earlier, if sunk costs matter current participation will depend upon the exporting history.

Table 6 provides detailed information on all the variables discussed above. All nominal variables have been deflated using specific industry deflators according to 20 sectors of the NACE-93 classification. Given that for some variables the direction of causality remains uncertain, in the estimation we lag one year firm characteristics and other exogenous variables to avoid possible simultaneity problems.

\footnotetext{
${ }^{19}$ See Bernard and Jensen (2004) and Clerides et al. (1998).
} 
Table 6: Variables definition.

\begin{tabular}{|c|c|}
\hline$y_{i, t-1}$ & $\begin{array}{l}\text { Dummy variable taking value one if the firm exported in year } t-1 \text { and zero } \\
\text { otherwise. }\end{array}$ \\
\hline$\tilde{y}_{i, t-2}$ & $\begin{array}{l}\text { Dummy variable taking value one if the firm was last in the export market two } \\
\text { years ago and zero otherwise. }\end{array}$ \\
\hline$\tilde{y}_{i, t-3}$ & $\begin{array}{l}\text { Dummy variable taking value one if the firm was last in the export market three } \\
\text { years ago and zero otherwise. }\end{array}$ \\
\hline Year dummies & Dummy variables taking value one for the corresponding year and zero otherwise. \\
\hline Age & Log of the number of years since the firm was born. \\
\hline Size & Log of the number of employees. \\
\hline Productivity & Log of labour productivity. \\
\hline Labour quality & Ratio of the number of highly qualified workers to total employment (in \%). \\
\hline Corporation & $\begin{array}{l}\text { Dummy variable taking value one if the firm is a limited liability corporation and } \\
\text { zero otherwise. }\end{array}$ \\
\hline Foreign & $\begin{array}{l}\text { Dummy variable taking value one if more than } 25 \% \text { of the firm shares are foreign } \\
\text { owned and zero otherwise. }\end{array}$ \\
\hline Domestic demand growth & Growth rate of domestic sales in real terms (in \%). \\
\hline Public sales & $\begin{array}{l}\text { Dummy variable taking value one if more than } 25 \% \text { of firm sales go to the public } \\
\text { sector and zero otherwise. }\end{array}$ \\
\hline R\&D intensity & R\&D expenditure normalized by sales (in \%). \\
\hline Complementary R\&D & $\begin{array}{l}\text { Dummy variable taking value one if the firm does any of the following activities: } \\
\text { technical and scientific information services, quality normalization and control, } \\
\text { imported technology assimilation efforts or design activities, and zero otherwise. }\end{array}$ \\
\hline $\mathrm{R} \& \mathrm{D}$ results & $\begin{array}{l}\text { Dummy variable taking value one if the firm registers patents or process } \\
\text { innovations and zero otherwise. }\end{array}$ \\
\hline Advertising intensity & Advertising expenditure normalized by sales (in \%). \\
\hline Region-specific spillovers & $\begin{array}{l}\text { Proportion of exporting firms in the region but outside the corresponding NACE- } \\
93 \text { industry. }\end{array}$ \\
\hline Industry-specific spillovers & $\begin{array}{l}\text { Proportion of exporting firms in the NACE- } 93 \text { industry but outside a given } \\
\text { region. }\end{array}$ \\
\hline Local-spillovers & Proportion of exporting firms in the region and the NACE-93 industry. \\
\hline Size group & $\begin{array}{l}\text { Dummy variable taking value one if the firm has more than } 200 \text { workers and zero } \\
\text { otherwise. }\end{array}$ \\
\hline \multirow[t]{21}{*}{ Industry dummies } & 20 sectors of the NACE-93 classification: \\
\hline & 1. Meat industry. \\
\hline & 2. Food and tobacco. \\
\hline & 3. Beverages. \\
\hline & 4. Textiles. \\
\hline & 5. Leather and shoes. \\
\hline & 6. Wood. \\
\hline & 7. Paper Industry. \\
\hline & 8. Printing and printing stuff. \\
\hline & 9. Chemical products. \\
\hline & 10. Rubber and plastic products. \\
\hline & 11. Non metallic miner products. \\
\hline & 12. Metallurgy. \\
\hline & 13. Metallic products. \\
\hline & 14. Machinery and mechanic equipment. \\
\hline & 15. Office machines. \\
\hline & 16. Electronic and electric machinery and material. \\
\hline & 17. Motors and cars. \\
\hline & 18. Other transport material. \\
\hline & 19. Furniture. \\
\hline & 20. Other manufacturing goods. \\
\hline
\end{tabular}




\section{Estimation results.}

We treat the period 1991-1993 as the $J=3$ pre-sample years controlling for the initial conditions problem. The values of the variables in 1990 are included as regressors for the 1991 initial condition. The observations for 1994-2000 are used to estimate the relevant parameters in equation 10 .

In Table 7 we report the PSML estimator. A test for joint significance of all the $\rho$-correlation coefficients leads to rejection of the null hypothesis that they are jointly equal to zero. Hence, the proper estimation method involves multivariate probit models. Furthermore, we also perform a test for endogeneity of initial conditions by testing the joint significance of $\rho$-correlation coefficients between initial conditions $(1990<t \leq$ $1993)$ and sample years errors $(1993<t \leq 2000)$. Exogeneity of initial conditions is strongly rejected. Hence, initial conditions should not be treated as exogenous. 
Table 7: Dynamic random effects multivariate probit model.

\begin{tabular}{|c|c|c|}
\hline & Coeff. & Std. Er. \\
\hline$y_{i, t-1}$ & $2.003^{* * *}$ & $(0.280)$ \\
\hline$\tilde{y}_{i, t-2}$ & 0.170 & $(0.167)$ \\
\hline$\tilde{y}_{i, t-3}$ & -0.297 & $(0.187)$ \\
\hline Year 1995 & $0.185^{*}$ & $(0.104)$ \\
\hline Year 1996 & 0.078 & $(0.099)$ \\
\hline Year 1997 & 0.158 & $(0.107)$ \\
\hline Year 1998 & 0.093 & $(0.100)$ \\
\hline Year 1999 & -0.014 & $(0.106)$ \\
\hline Year 2000 & $0.184^{*}$ & $(0.106)$ \\
\hline Size & $0.265^{* * *}$ & $(0.054)$ \\
\hline Productivity & $0.341^{* * *}$ & $(0.057)$ \\
\hline Age & 0.089 & $(0.073)$ \\
\hline Labour quality & -0.004 & $(0.009)$ \\
\hline Corporate & 0.062 & $(0.080)$ \\
\hline Foreign & 0.029 & $(0.125)$ \\
\hline Domestic demand growth & $3.5 \mathrm{e}-06$ & $(3.9 \mathrm{e}-06)$ \\
\hline Public Sales & $-0.328^{* *}$ & $(0.167)$ \\
\hline $\mathrm{R} \& \mathrm{D}$ intensity & $0.032^{* *}$ & $(0.013)$ \\
\hline Complementary R\&D & $0.131^{* *}$ & $(0.060)$ \\
\hline R\&D results & 0.012 & $(0.065)$ \\
\hline Advertising & $0.031^{* * *}$ & $(0.010)$ \\
\hline Regional Spillovers & $0.004^{*}$ & $(0.002)$ \\
\hline Industry Spillovers & -0.001 & $(0.003)$ \\
\hline Local Spillovers & -0.002 & $(0.002)$ \\
\hline Size group & -0.088 & $(0.114)$ \\
\hline Food and tobacco & $-0.437^{* *}$ & $(0.222)$ \\
\hline Beverages & -0.502 & $(0.333)$ \\
\hline Textiles & 0.203 & $(0.217)$ \\
\hline Leather and shoes & $0.556^{* *}$ & $(0.259)$ \\
\hline Wood & 0.239 & $(0.255)$ \\
\hline Paper & -0.239 & $(0.239)$ \\
\hline Printing & -0.180 & $(0.244)$ \\
\hline Chemical products & 0.005 & $(0.266)$ \\
\hline Rubber and plastic & 0.359 & $(0.249)$ \\
\hline Non metallic miner & -0.056 & $(0.219)$ \\
\hline Metallurgy & 0.405 & $(0.285)$ \\
\hline Metallic products & 0.003 & $(0.204)$ \\
\hline Machinery and mech. eq. & 0.285 & $(0.241)$ \\
\hline Office machines & 0.282 & $(0.505)$ \\
\hline Electronic & -0.160 & $(0.217)$ \\
\hline Motors and cars & 0.294 & $(0.254)$ \\
\hline Other transport material & -0.065 & $(0.257)$ \\
\hline Furniture & $0.367^{*}$ & $(0.219)$ \\
\hline Other manufacturing goods & $1.092^{* * *}$ & $(0.381)$ \\
\hline Intercept & $-5.314^{* * *}$ & $(0.574)$ \\
\hline
\end{tabular}

1. Test Ho: $\rho_{t s}, \forall t \neq s$, jointly equal to zero:

$\chi_{45}^{2}=485.58 ; p$-value $=0.000$

2. Test Ho:

$\rho_{\text {ts }}, \forall t(1990<t \leq 1993)$ and $s(1993<s \leq 2000)$, jointly equal to zero:

$\chi_{21}^{2}=125.18 ; p$-value $=0.000$ 


\subsection{Sunk costs parameters.}

A Wald test for joint significance of the coefficients of $y_{i, t-1}, \tilde{y}_{i, t-2}$ and $\tilde{y}_{i, t-3}$ suggests the rejection of the hypothesis that they are jointly equal to 0 , with a $\chi_{3}^{2}$ statistic of 67.56 and a $p$-value approximately 0 . Hence, even after controlling for a general form of serial correlation, exporting history matters.

Regarding individual coefficients, the coefficient of $y_{i, t-1}$ is large, positive and significant, revealing that exporting the previous year has a strong positive impact on the probability of exporting this year. Additionally, this coefficient can be considered as an estimate of the sum of sunk entry costs for a firm that never exported and exit costs for current exporters ("hysteresis band", Dixit, 1989a). The coefficients of $\tilde{y}_{i, t-2}$ and $\tilde{y}_{i, t-3}$ measure, respectively, the reductions in the full sunk entry costs faced by a new exporter enjoyed by firms that exported for the last time two and three years ago. Both coefficients are non significant, indicating a rapid depreciation of exporting experience; i.e. there is no significant difference between the entry cost of a firm that last exported two or three years ago and a firm that had never exported before. ${ }^{20}$

\subsection{Time dummies, firm/market characteristics and spillovers.}

We analyse next the impact of time dummies, firm/market characteristics and spillovers on the expected profits, net of sunk entry costs $\left(\pi_{i t}^{*}-F^{0}\right)$, of a firm with no previous experience in the export market. The 1995 and 2000 dummy coefficients are positive and significant at an $8 \%$ level. The estimate of the dummy for 1995 is probably capturing the peseta depreciation that took place after the bandwidth widening of the European Rate Mechanism. The dummy for 2000 could be reflecting the depreciation of the euro with respect to the US dollar. ${ }^{21}$ In addition, the hypothesis that the time dummies are jointly equal to zero cannot be rejected (the $\chi_{6}^{2}$ test is 8.28 and the corresponding $p$-value 0.218 ). This partial lack of responsiveness could suggest that the export decision is rather insensitive to macro conditions during the sample period.

\footnotetext{
${ }^{20}$ Our results are similar to those in Roberts and Tybout (1997). Bernard and Wagner (1998) and Bernard and Jensen (2004) include only two lags of export participation and both of them are found to be significant.

${ }^{21}$ From $1^{\text {st }}$ January 1999 exchange rates between the European Monetary Union national currencies are fixed and euro-dollar exchange rates determine the exchange rates between national currencies of the European Monetary Union and the US dollar.
} 
We also analyse the influence of observable firm/market characteristics. Only two out of the three variables included to proxy for firm past success have an impact on net export profitability: size (measured by the number of workers) and productivity. Larger and more productive firms are more likely to become exporters. The coefficient on age, often considered as a proxy for efficiency, is not significant. ${ }^{22}$

The coefficient on the variable that proxies for labour force quality is not significant. ${ }^{23}$ However, this does not necessarily mean that a better quality of the labour force will not help to succeed in the export market. A more qualified labour force may contribute to vertically differentiate the firm product. However, the extent of product differentiation is better captured by other vertical product differentiation variables included in the analysis.

Neither corporate ownership nor foreign capital participation are significant determinants of export participation. ${ }^{24}$ The result on the foreign capital participation variable could be signalling that the aim of foreign investors is not necessarily using Spain as a productive platform but supplying the domestic market.

As regards the influence of domestic demand factors, the evolution of domestic demand (measured by its growth rate) is not significant. However, firms selling a relevant part of their production to the public sector show a lower probability of exporting.

The probability of exporting increases with vertical product differentiation. Two of the three variables introduced to account for this effect are significant: the probability of exporting increases both with the intensity of R\&D expenditure and with the realization of $\mathrm{R} \& \mathrm{D}$ complementary activities such as quality controls or product normalization.

\footnotetext{
${ }^{22}$ Roberts and Tybout (1997), Bernard and Wagner (1998) and Bernard and Jensen (2004) find that size affects positively the probability of exporting. Productivity appears non significant in most of specifications in Bernard and Jensen (2004). However, it is significant in most cases in Bernard and Wagner (1998). As for age, Roberts and Tybout (1997) find that older plants are more likely to export. The lack of significance of the variable age in our analysis may be due to the inclusion of the variable productivity, that might be capturing differences in efficiency that in Roberst and Tybout (1997) are picked up by the age variable.

${ }^{23}$ Bernard and Wagner (1998) and Bernard and Jensen (2004) find significant and non significant effects of this variable, respectively.

${ }^{24}$ However, in Roberts and Tybout (1997) corporate ownership positively influences the probability of exporting.
} 
The third variable, which controls whether the firm registers patents or process innovations, is not significant. This could be suggesting that patenting does not ensure exporting success. Horizontal product differentiation has also a positive impact on the probability of exporting, as it shows a positive and significant coefficient for advertising intensity.

Looking at spillovers, only regional spillovers seem to have a positive and significant impact on the probability of exporting. This may suggest that the presence of other exporting firms in the same region lowers the cost of entry in the export market, possibly by increasing the availability of specialized inputs such as exporting networks or workers with previous experience in the export market. ${ }^{25}$

Finally, belonging to one or the other size group (more than 200 employees or less than 200) does not seem to influence the probability of exporting. This variable was included to capture a potential effect of the different sampling schemes for the two different size groups in the ESEE.

\subsection{Goodness of fit.}

Following Roberts and Tybout (1997), to evaluate the goodness of fit of our model, we compare actual and predicted patterns of export market participation. For the seven-year period 1994-2000 there are 128 (that is, $2^{7}$ ) possible export market trajectories for an individual firm. ${ }^{26}$ Across the 755 firms of our sample, some of these trajectories are either never observed or are quite unusual. Hence, to simplify the comparison of actual and predicted trajectories, we group the 128 possible trajectories into 6 categories based on two criteria: first, the firm exporting status in 1994; and second, whether the firm changes exporting status once or more times between 1995 and 2000. Table 8 shows that actual and predicted frequencies for the six categories are quite similar. Furthermore, the results of a chi-square contingency table test, comparing actual and predicted frequencies $\left(\chi^{2}=0.654\right.$ with a $p$-value of 0.985$)$, indicate that there are not significant differences between the two.

\footnotetext{
25 Bernard and Jensen (2004) introduce the same three measures of spillovers but these are always nonsignificant or have a negative sign (contrary to expected).

${ }^{26}$ Actual and predicted frequencies for the complete 128 possible trajectories are shown in the Appendix.
} 
These results suggest that our functional form, lags and error structure are appropriate and that our model predicts patterns of export market participation rather accurately.

Table 8: Observed vs. predicted frequencies of $y_{i t}$ trajectories.

\begin{tabular}{lcr}
\hline Trajectory type & $\begin{array}{c}\text { Observed } \\
\text { frequencies }\end{array}$ & $\begin{array}{c}\text { Predicted } \\
\text { frequencies }\end{array}$ \\
\hline Always a non exporter & 0.290 & 0.289 \\
Begin as non exporter, switch once & 0.097 & 0.095 \\
Begin as non exporter, switch at least twice & 0.072 & 0.081 \\
Always an exporter & 0.479 & 0.472 \\
Begin as an exporter, switch once & 0.024 & 0.021 \\
Begin as an exporter, switch at least twice & 0.038 & 0.041 \\
\hline
\end{tabular}

\section{Concluding remarks.}

In this paper, we test the existence of sunk costs in the export decision by Spanish manufacturing firms. We use a dynamic random effects multivariate probit model that allows controlling for competing sources of persistence: sunk costs, heterogeneity and serial correlation in transitory shocks. The data used have been drawn from the ESEE survey for the period 1990-2000. This survey is representative of Spanish manufacturing firms. This paper differs from the existing literature in the following respects. First, we use a richer set of firm characteristics (including vertical and horizontal product differentiation variables) and market characteristics (including industry, regional and local spillovers) that allows for a better identification of sunk costs. Secondly, we do not impose any structure on the serial correlation of transitory shocks. Misspecification problems may arise from a given structure and may lead to inconsistent estimates for sunk costs. Thirdly, whereas most previous studies use plant data, our observation unit is the firm, which is the appropriate one to analyse the export decision.

We find evidence supporting the sunk cost explanation for hysteresis in Spanish manufacturing exports. Furthermore, our estimation results indicate that those firms leaving the export market suffer a rapid depreciation of their exporting experience. Reentry costs that faces a firm that last exported two or three years ago are not significantly different from those faced by a new exporter. This phenomenon could be suggesting, for instance, that obtaining information about foreign demand conditions is an important source of sunk costs of entry and that this information rapidly depreciates once a firm leaves the export market. Firm heterogeneity is also an important source of persistence in the export market, as firm characteristics are relevant to explain firms' 
exporting trajectories. Firms' past success (as measured by size and productivity) has a positive impact on the probability to export. Product differentiation also increases this probability. As regards vertical product differentiation, the probability of exporting increases with the intensity of $R \& D$ expenditure and with the realization of other $R \& D$ related activities such as quality controls or product normalization. Firms that horizontally differentiate their products by means of advertising also have a higher probability of exporting. Finally, regional spillovers (presence of other exporting firms in the same region) affect positively the probability of exporting.

Our findings make a significant contribution to the understanding of the determinants of firms' decision to export and have important implications for public policy. The combined relevance of sunk costs and firm characteristics in the probability of exporting suggest possible export promotion policies. On the one hand, policies directed at providing information and access to foreign markets or providing exporting infrastructures could reduce the sunk costs of entry. On the other hand, policies aimed to help firms to increase productivity or to stimulate product differentiation behaviours would have a positive impact on exporting. 


\section{References.}

Baily, M.N., Charles, H., Campbell, D., 1992. Productivity dynamics in manufacturing firms. Brookings Papers on Economic Activity, Microeconomics, pp. 187--249.

Baldwin, R.E., 1988. Hysteresis in import prices: the beachhead effect. American Economic Review 78, pp. 773--785.

Baldwin, R.E., 1989. Sunk costs hysteresis. National Bureau of Economic Research 2911.

Baldwin, R.E., Krugman, P.R., 1989. Persistent trade effects of large exchange rate shocks. Quarterly Journal of Economics 104(4), pp. 635--654.

Baldwin, J.R., Rafiquzzaman, M., 1995. Selection versus evolutionary adaptation: learning and post-entry performance. International Journal of Industrial Organization 13, pp. 501-522.

Bernard, A.B., Wagner, J., 1998. Export entry and exit by German firms. National Bureau of Economic Research 6538.

Bernard, A.B., Jensen, J.B., 1999. Exceptional exporter performance: Cause , effect, or both? Journal of International Economics 47, pp. 1--25.

Bernard, A.B., Jensen, J.B., 2004. Why some firms export? Review of Economics and Statistics $86(2)$, pp. 561--569.

Binder, D.A., 1983. On the variances of asymptotically normal estimators from complex surveys. International Statistical Review 51, pp. 279--292.

Campa, J.M., 2004. Exchange rates and trade: How important is hysteresis in trade? European Economic Review 48, pp. 527--548.

Cappellari, L., Jenkins, S.P., 2003. Multivariate probit regression using simulated maximum likelihood. ISER, University of Essex.

Clerides, S.K., Lach, S., Tybout, J.R., 1998. Is learning by exporting important? Micro-dynamic evidence from Colombia, Mexico, and Morocco. The Quarterly Journal of Economics, pp. 903--947.

Delgado, M. A., Fariñas, J. C., Ruano, S., 2002. Firm productivity and export markets: a non-parametric approach. Journal of International Economics 57, pp. 397--422.

Dixit, A., 1989a. Entry and exit decision under uncertainty. Journal of Political Economy 97(3), pp. $620--638$.

Dixit, A., 1989b. Hysteresis import penetration exchange rate pass-through. Quarterly Journal of Economics 104, pp. 205--228.

Dunne, T., Roberts, M.J., Samuelson, L., 1989. The growth and failure of U.S. manufacturing plants. Quarterly Journal of Economics 105(4), pp. 671--698. 
Ericson, R., Pakes, A., 1995. Markov-perfect industry dynamics: a framework for empirical work. Review of Economic Studies 62, pp. 53--82.

Esteve, S., Sanchis, A., Sanchis, J.A., 2003. The determinants of survival of Spanish manufacturing firms. Departamento de Estructura Económica, Universidad de Valencia, mimeo.

Gourieroux, C., Monfort, A., 1996. Simulation-based econometric methods. University Press, Oxford.

Hajivassiliou, V., Ruud, P., 1994. Classical estimation methods for LDV models using simulation, in: Engle, R., McFadden, D. (Eds.), Handbook of Econometrics. NorthHolland, Amsterdam, pp. 2383--2441.

Heckman, J.J., 1981. The incidental parameters problem and the problem of initial conditions in estimating a discrete time-discrete data stochastic process, in: Manski, C., McFadden, D. (Eds.), The structural analysis of discrete data. MIT Press, Cambridge, pp. 179--195.

Huber, P.J., 1967. The behaviour of maximum likelihood estimators under non-standard conditions, in: Proceedings of the Fifth Berkeley Symposium in Mathematical Statistics and Probability. University of California Press, Berkeley CA, pp. 221--233.

Krugman P.R., 1984. Import protection as export promotion: International competition in the presence of oligopoly and economies of scale, in: Kierzkowski, H. (Ed.), Monopolistic competition and international trade. University Press, Oxford, pp. 180--193.

Krugman P.R., 1989. Exchange-rate instability. MIT Press, Cambridge.

Pakes A., Ericson, R., 1998. Empirical implications of alternative models of firm dynamics. Journal of Economic Theory 79, pp. 1--45.

Roberts, M.J., 1996. Colombia 1977-1985: Producer, turnover, margins and trade exposure, in: Roberts, M.J., Tybout, J.R. (Eds.), Industrial evolution in developing countries: Micro patterns of turnover, productivity and market structure. University Press, Oxford, pp. 227--259.

Roberts M.J., Tybout, J.R., 1997. The Decision to Export in Colombia: An Empirical Model of Entry with Sunk Costs. American Economic Review 87, pp. 545--564.

Tybout, J.R., 1996. Chile, 1979-1986: Trade liberalization and its aftermath, in: Roberts, M.J., Tybout, J.R. (Eds.), Industrial evolution in developing countries: Micro patterns of turnover, productivity and market structure. University Press, Oxford, pp. 200--226.

White, H., 1982. Maximum likelihood estimation of misspecified models. Econometrica 50, pp. $1-25$. 
Appendix.

Actual and predicted frequencies.

\begin{tabular}{|c|c|c|c|c|c|c|c|c|c|c|c|c|c|c|c|c|c|}
\hline \multicolumn{7}{|c|}{ Export Status } & \multirow[b]{2}{*}{$\begin{array}{c}\text { Actual } \\
\text { Frequency }\end{array}$} & \multirow[b]{2}{*}{$\begin{array}{l}\text { Expected } \\
\text { Frequency }\end{array}$} & \multicolumn{7}{|c|}{ Export Status } & \multirow[b]{2}{*}{$\begin{array}{c}\text { Actual } \\
\text { Frequency }\end{array}$} & \multirow[b]{2}{*}{$\begin{array}{l}\text { Expected } \\
\text { Frequency }\end{array}$} \\
\hline 94 & 95 & 96 & 97 & 98 & 99 & 00 & & & 94 & 95 & 96 & 97 & 98 & 99 & 00 & & \\
\hline 1 & 1 & 1 & 1 & 1 & 1 & 1 & 0.479 & 0.472 & 0 & 1 & 1 & 1 & 1 & 1 & 1 & 0.028 & 0.023 \\
\hline 1 & 1 & 1 & 1 & 1 & 1 & 0 & 0.005 & 0.004 & 0 & 1 & 1 & 1 & 1 & 1 & 0 & 0.000 & 0.004 \\
\hline 1 & 1 & 1 & 1 & 1 & 0 & 1 & 0.001 & 0.001 & 0 & 1 & 1 & 1 & 1 & 0 & 1 & 0.001 & 0.001 \\
\hline 1 & 1 & 1 & 1 & 1 & 0 & 0 & 0.009 & 0.003 & 0 & 1 & 1 & 1 & 1 & 0 & 0 & 0.001 & 0.003 \\
\hline 1 & 1 & 1 & 1 & 0 & 1 & 1 & 0.000 & 0.003 & 0 & 1 & 1 & 1 & 0 & 1 & 1 & 0.000 & 0.003 \\
\hline 1 & 1 & 1 & 1 & 0 & 1 & 0 & 0.001 & 0.000 & 0 & 1 & 1 & 1 & 0 & 1 & 0 & 0.000 & 0.000 \\
\hline 1 & 1 & 1 & 1 & 0 & 0 & 1 & 0.001 & 0.003 & 0 & 1 & 1 & 1 & 0 & 0 & 1 & 0.000 & 0.000 \\
\hline 1 & 1 & 1 & 1 & 0 & 0 & 0 & 0.001 & 0.001 & 0 & 1 & 1 & 1 & 0 & 0 & 0 & 0.004 & 0.004 \\
\hline 1 & 1 & 1 & 0 & 1 & 1 & 1 & 0.004 & 0.003 & 0 & 1 & 1 & 0 & 1 & 1 & 1 & 0.001 & 0.000 \\
\hline 1 & 1 & 1 & 0 & 1 & 1 & 0 & 0.000 & 0.000 & 0 & 1 & 1 & 0 & 1 & 1 & 0 & 0.000 & 0.000 \\
\hline 1 & 1 & 1 & 0 & 1 & 0 & 1 & 0.000 & 0.000 & 0 & 1 & 1 & 0 & 1 & 0 & 1 & 0.000 & 0.000 \\
\hline 1 & 1 & 1 & 0 & 1 & 0 & 0 & 0.000 & 0.000 & 0 & 1 & 1 & 0 & 1 & 0 & 0 & 0.000 & 0.000 \\
\hline 1 & 1 & 1 & 0 & 0 & 1 & 1 & 0.001 & 0.000 & 0 & 1 & 1 & 0 & 0 & 1 & 1 & 0.000 & 0.001 \\
\hline 1 & 1 & 1 & 0 & 0 & 1 & 0 & 0.000 & 0.000 & 0 & 1 & 1 & 0 & 0 & 1 & 0 & 0.001 & 0.000 \\
\hline 1 & 1 & 1 & 0 & 0 & 0 & 1 & 0.004 & 0.001 & 0 & 1 & 1 & 0 & 0 & 0 & 1 & 0.000 & 0.001 \\
\hline 1 & 1 & 1 & 0 & 0 & 0 & 0 & 0.003 & 0.000 & 0 & 1 & 1 & 0 & 0 & 0 & 0 & 0.005 & 0.000 \\
\hline 1 & 1 & 0 & 1 & 1 & 1 & 1 & 0.003 & 0.005 & 0 & 1 & 0 & 1 & 1 & 1 & 1 & 0.001 & 0.003 \\
\hline 1 & 1 & 0 & 1 & 1 & 1 & 0 & 0.001 & 0.000 & 0 & 1 & 0 & 1 & 1 & 1 & 0 & 0.000 & 0.000 \\
\hline 1 & 1 & 0 & 1 & 1 & 0 & 1 & 0.000 & 0.003 & 0 & 1 & 0 & 1 & 1 & 0 & 1 & 0.000 & 0.000 \\
\hline 1 & 1 & 0 & 1 & 1 & 0 & 0 & 0.000 & 0.000 & 0 & 1 & 0 & 1 & 1 & 0 & 0 & 0.000 & 0.000 \\
\hline 1 & 1 & 0 & 1 & 0 & 1 & 1 & 0.000 & 0.000 & 0 & 1 & 0 & 1 & 0 & 1 & 1 & 0.000 & 0.000 \\
\hline 1 & 1 & 0 & 1 & 0 & 1 & 0 & 0.000 & 0.000 & 0 & 1 & 0 & 1 & 0 & 1 & 0 & 0.000 & 0.000 \\
\hline 1 & 1 & 0 & 1 & 0 & 0 & 1 & 0.000 & 0.000 & 0 & 1 & 0 & 1 & 0 & 0 & 1 & 0.000 & 0.000 \\
\hline 1 & 1 & 0 & 1 & 0 & 0 & 0 & 0.000 & 0.001 & 0 & 1 & 0 & 1 & 0 & 0 & 0 & 0.001 & 0.000 \\
\hline 1 & 1 & 0 & 0 & 1 & 1 & 1 & 0.001 & 0.000 & 0 & 1 & 0 & 0 & 1 & 1 & 1 & 0.000 & 0.000 \\
\hline 1 & 1 & 0 & 0 & 1 & 1 & 0 & 0.000 & 0.000 & 0 & 1 & 0 & 0 & 1 & 1 & 0 & 0.000 & 0.000 \\
\hline 1 & 1 & 0 & 0 & 1 & 0 & 1 & 0.000 & 0.000 & 0 & 1 & 0 & 0 & 1 & 0 & 1 & 0.000 & 0.000 \\
\hline 1 & 1 & 0 & 0 & 1 & 0 & 0 & 0.000 & 0.000 & 0 & 1 & 0 & 0 & 1 & 0 & 0 & 0.000 & 0.000 \\
\hline 1 & 1 & 0 & 0 & 0 & 1 & 1 & 0.004 & 0.000 & 0 & 1 & 0 & 0 & 0 & 1 & 1 & 0.003 & 0.000 \\
\hline 1 & 1 & 0 & 0 & 0 & 1 & 0 & 0.000 & 0.000 & 0 & 1 & 0 & 0 & 0 & 1 & 0 & 0.000 & 0.000 \\
\hline 1 & 1 & 0 & 0 & 0 & 0 & 1 & 0.000 & 0.001 & 0 & 1 & 0 & 0 & 0 & 0 & 1 & 0.001 & 0.001 \\
\hline 1 & 1 & 0 & 0 & 0 & 0 & 0 & 0.001 & 0.004 & 0 & 1 & 0 & 0 & 0 & 0 & 0 & 0.004 & 0.004 \\
\hline 1 & 0 & 1 & 1 & 1 & 1 & 1 & 0.007 & 0.009 & 0 & 0 & 1 & 1 & 1 & 1 & 1 & 0.008 & 0.020 \\
\hline 1 & 0 & 1 & 1 & 1 & 1 & 0 & 0.000 & 0.000 & 0 & 0 & 1 & 1 & 1 & 1 & 0 & 0.000 & 0.001 \\
\hline 1 & 0 & 1 & 1 & 1 & 0 & 1 & 0.000 & 0.000 & 0 & 0 & 1 & 1 & 1 & 0 & 1 & 0.003 & 0.000 \\
\hline 1 & 0 & 1 & 1 & 1 & 0 & 0 & 0.000 & 0.000 & 0 & 0 & 1 & 1 & 1 & 0 & 0 & 0.003 & 0.003 \\
\hline 1 & 0 & 1 & 1 & 0 & 1 & 1 & 0.000 & 0.000 & 0 & 0 & 1 & 1 & 0 & 1 & 1 & 0.001 & 0.001 \\
\hline 1 & 0 & 1 & 1 & 0 & 1 & 0 & 0.000 & 0.000 & 0 & 0 & 1 & 1 & 0 & 1 & 0 & 0.000 & 0.000 \\
\hline 1 & 0 & 1 & 1 & 0 & 0 & 1 & 0.000 & 0.000 & 0 & 0 & 1 & 1 & 0 & 0 & 1 & 0.001 & 0.001 \\
\hline 1 & 0 & 1 & 1 & 0 & 0 & 0 & 0.000 & 0.000 & 0 & 0 & 1 & 1 & 0 & 0 & 0 & 0.004 & 0.005 \\
\hline 1 & 0 & 1 & 0 & 1 & 1 & 1 & 0.000 & 0.000 & 0 & 0 & 1 & 0 & 1 & 1 & 1 & 0.000 & 0.001 \\
\hline 1 & 0 & 1 & 0 & 1 & 1 & 0 & 0.001 & 0.000 & 0 & 0 & 1 & 0 & 1 & 1 & 0 & 0.000 & 0.000 \\
\hline 1 & 0 & 1 & 0 & 1 & 0 & 1 & 0.000 & 0.000 & 0 & 0 & 1 & 0 & 1 & 0 & 1 & 0.000 & 0.000 \\
\hline 1 & 0 & 1 & 0 & 1 & 0 & 0 & 0.000 & 0.001 & 0 & 0 & 1 & 0 & 1 & 0 & 0 & 0.000 & 0.000 \\
\hline 1 & 0 & 1 & 0 & 0 & 1 & 1 & 0.000 & 0.000 & 0 & 0 & 1 & 0 & 0 & 1 & 1 & 0.001 & 0.000 \\
\hline 1 & 0 & 1 & 0 & 0 & 1 & 0 & 0.000 & 0.000 & 0 & 0 & 1 & 0 & 0 & 1 & 0 & 0.000 & 0.000 \\
\hline 1 & 0 & 1 & 0 & 0 & 0 & 1 & 0.000 & 0.000 & 0 & 0 & 1 & 0 & 0 & 0 & 1 & 0.000 & 0.003 \\
\hline 1 & 0 & 1 & 0 & 0 & 0 & 0 & 0.001 & 0.001 & 0 & 0 & 1 & 0 & 0 & 0 & 0 & 0.003 & 0.004 \\
\hline 1 & 0 & 0 & 1 & 1 & 1 & 1 & 0.001 & 0.000 & 0 & 0 & 0 & 1 & 1 & 1 & 1 & 0.021 & 0.007 \\
\hline 1 & 0 & 0 & 1 & 1 & 1 & 0 & 0.000 & 0.000 & 0 & 0 & 0 & 1 & 1 & 1 & 0 & 0.003 & 0.005 \\
\hline 1 & 0 & 0 & 1 & 1 & 0 & 1 & 0.000 & 0.001 & 0 & 0 & 0 & 1 & 1 & 0 & 1 & 0.004 & 0.000 \\
\hline 1 & 0 & 0 & 1 & 1 & 0 & 0 & 0.000 & 0.000 & 0 & 0 & 0 & 1 & 1 & 0 & 0 & 0.004 & 0.005 \\
\hline 1 & 0 & 0 & 1 & 0 & 1 & 1 & 0.000 & 0.000 & 0 & 0 & 0 & 1 & 0 & 1 & 1 & 0.003 & 0.000 \\
\hline 1 & 0 & 0 & 1 & 0 & 1 & 0 & 0.000 & 0.000 & 0 & 0 & 0 & 1 & 0 & 1 & 0 & 0.000 & 0.000 \\
\hline 1 & 0 & 0 & 1 & 0 & 0 & 1 & 0.000 & 0.000 & 0 & 0 & 0 & 1 & 0 & 0 & 1 & 0.000 & 0.001 \\
\hline 1 & 0 & 0 & 1 & 0 & 0 & 0 & 0.000 & 0.000 & 0 & 0 & 0 & 1 & 0 & 0 & 0 & 0.007 & 0.003 \\
\hline 1 & 0 & 0 & 0 & 1 & 1 & 1 & 0.000 & 0.004 & 0 & 0 & 0 & 0 & 1 & 1 & 1 & 0.016 & 0.016 \\
\hline 1 & 0 & 0 & 0 & 1 & 1 & 0 & 0.000 & 0.000 & 0 & 0 & 0 & 0 & 1 & 1 & 0 & 0.001 & 0.007 \\
\hline 1 & 0 & 0 & 0 & 1 & 0 & 1 & 0.000 & 0.000 & 0 & 0 & 0 & 0 & 1 & 0 & 1 & 0.003 & 0.003 \\
\hline 1 & 0 & 0 & 0 & 1 & 0 & 0 & 0.000 & 0.000 & 0 & 0 & 0 & 0 & 1 & 0 & 0 & 0.004 & 0.007 \\
\hline 1 & 0 & 0 & 0 & 0 & 1 & 1 & 0.003 & 0.001 & 0 & 0 & 0 & 0 & 0 & 1 & 1 & 0.009 & 0.017 \\
\hline 1 & 0 & 0 & 0 & 0 & 1 & 0 & 0.000 & 0.000 & 0 & 0 & 0 & 0 & 0 & 1 & 0 & 0.003 & 0.005 \\
\hline 1 & 0 & 0 & 0 & 0 & 0 & 1 & 0.003 & 0.001 & 0 & 0 & 0 & 0 & 0 & 0 & 1 & 0.015 & 0.013 \\
\hline 1 & 0 & 0 & 0 & 0 & 0 & 0 & 0.004 & 0.009 & 0 & 0 & 0 & 0 & 0 & 0 & 0 & 0.290 & 0.289 \\
\hline
\end{tabular}

